\title{
Quadrigyrus torquatus cystacants Van Cleave, 1920 (Acanthocephala: Quadrigyridae) parasitizing species of Astyanax (Characiformes: Characidae) from southern Brazil
}

\author{
Moisés Gallas $^{1 *}$ \& \& Laura R. P. Utz ${ }^{1}$ \\ ${ }^{1}$ Pontifícia Universidade Católica do Rio Grande do Sul, Faculdade de Biociências, Laboratório de Ecologia \\ Aquática, Porto Alegre, RS, Brasil \\ *Corresponding author: Moisés Gallas, e-mail: mgallas88@gmail.com
}

GALLAS, M., UTZ, L. R. P. Quadrigyrus torquatus cystacants Van Cleave, 1920 (Acanthocephala: Quadrigyridae) parasitizing species of Astyanax (Characiformes: Characidae) from southern Brazil. Biota Neotropica. 19(3): e20180693. http://dx.doi.org/10.1590/1676-0611-BN-2018-0693

\begin{abstract}
The acanthocephalan species Quadrigyrus torquatus Van Cleave, 1920 has been found in different hosts from South America, but recent papers have not focused on its morphology traits. Different species of Astyanax Baird \& Girard, 1854 were collected with seine nets between January 2017 and October 2017 in Pintada Island, Lake Guaíba, Porto Alegre city ( $30^{\circ} 17^{\prime} 11^{\prime}$ 'S and $51^{\circ} 18$ '01'W), Rio Grande do Sul State, Brazil. Acanthocephalans found in cysts were processed according to the techniques for the group. Specimens of $Q$. torquatus were identified based mainly in the morphology of proboscis hooks and trunk spines, and by the measurements made using light microscopy. Supplemental observations on the morphology of $Q$. torquatus were made for the first time considering the morphology and amount of hooks and spines. The amplitude of intensity of infections was 1 (A. aff. fasciatus) and 1-3 (A. lacustris) helminths. This difference could be related to the number of hosts examined, the feeding habit of the hosts or related to aspects in the parasite life cycle. This paper is the first report of Q. torquatus in A. aff. fasciatus and A. lacustris from Lake Guaíba, extending the distribution to the southernmost state of Brazil, thus contributing to the knowledge of acanthocephalans in freshwater fishes from South America.
\end{abstract}

Keywords: Acanthocephalan, helminths, endoparasite, taxonomy, Neotropical region.

\section{Cistacantos de Quadrigyrus torquatus Van Cleave, 1920 (Acanthocephala: Quadrigyridae) parasitando espécies de Astyanax (Characiformes: Characidae) no sul do Brasil}

Resumo: A espécie de acantocéfalo Quadrigyrus torquatus Van Cleave, 1920, tem sido encontrada em diferentes hospedeiros na América do Sul, contudo os estudos recentes não focam no estudo dos caracteres morfológicos. Diferentes espécies de Astyanax Baird \& Girard, 1854 foram coletadas com redes do tipo picaré entre janeiro e outubro de 2017, na Ilha da Pintada, Lago Guaíba, Cidade de Porto Alegre (30¹7'11'’S e 51¹8'01"W), Estado do Rio Grande do Sul, Brasil. Os acantocéfalos encontrados encistados foram processados de acordo com as técnicas para o grupo. Os espécimes de $Q$. torquatus foram identificados principalmente pela morfologia dos ganchos da probóscide, espinhos do tronco e, pelas medidas realizadas através de microscopia de luz. Observações suplementares na morfologia de $Q$. torquatus foram realizadas pela primeira vez, considerando a morfologia e o número de ganchos e espinhos. A amplitude das infecções foi 1 (A. aff. fasciatus) e 1-3 (A. lacustris) helmintos. Esta diferença pode estar associada com o número de hospedeiros examinados, com os hábitos alimentares dos hospedeiros, ou relacionada com aspectos no ciclo de vida do parasito. Este estudo é o primeiro registro de $Q$. torquatus em $A$. aff. fasciatus e A. lacustris do Lago Guaíba, estendendo a distribuição do parasito para o sul do Brasil, contribuindo com o conhecimento dos acantocéfalos parasitos de peixes de água doce na América do Sul. Palavras-chave: Acantocéfalo, helmintos, endoparasito, taxonomia, região Neotropical. 


\section{Introduction}

According to the most recent proposal of classification of acanthocephalans, the family Quadrigyridae Van Cleave, 1920 encompasses two subfamilies: Pallisentinae Van Cleave, 1928 and Quadrigyrinae Van Cleave, 1920. The genera Acanthodelta DiazUngria \& Garcia-Rodrigo, 1958, Machadosenstis Noronha, 1992 and Quadrigyrus Van Cleave, 1920 are currently assigned to the subfamily Quadrigyrinae (Amin 2013).

Van Cleave (1920) when proposed the genus Quadrigyrus, described Quadrigyrus torquatus Van Cleave, 1920 as type-species. At that time, the species description was based on specimens of $Q$. torquatus collected from Hoplias malabaricus (Bloch, 1794) in the Lake Valencia, city of Maracay (type-locality) and in Isla de Burro, both in Venezuela. This author found the parasite in other hosts: Synbranchus marmoratus Bloch, 1795, Crenicichla geayi Pellegrin, 1903, Gephyrocharax valencia Eigenmann, 1920 and Astyanax bimaculatus (Linnaeus, 1758). Until now, nine species of Quadrigyrus are considered valid (Amin 2013). From these, four species (Quadrigyrus brasiliensis Machado Filho, 1941, Quadrigyrus machadoi Fabio, 1983, Quadrigyrus nickoli Schmidt \& Hugghins, 1973 and Q. torquatus) were reported from South America (Thatcher 2006, Santos et al. 2008, Fujimoto et al. 2013).

A total of 20 species of Astyanax Baird \& Girard, 1854 have been reported from Rio Grande do Sul State, southern Brazil. These species are found in the Uruguay river drainage basin, Patos Lagoon system, and in Tramandaí river system (Lucena et al. 2017). In Lake Guaíba the following species of Astyanax have been considered abundant: Astyanax eigenmanniorum (Cope, 1894), Astyanax aff. fasciatus (Cuvier, 1819), Astyanax henseli Melo \& Buckup, 2006 and Astyanax lacustris (Lütken, 1875). Until now, two species of digenetic trematodes, two species of monogeneans and one species of nematode were recorded from species of Astyanax in the Lake Guaíba (Fortes \& Hoffmann 1999, Gallas et al. 2014, 2015, 2016), but no acanthocephalans were observed parasitizing species of this genus.

In Brazil, there are reports of Q. torquatus from different hosts collected in States of Pará, Mato Grosso, Rio de Janeiro and Paraná (Machado Filho 1941, Carvalho et al. 2003, Guidelli et al. 2006, Santos et al. 2008, Fujimoto et al. 2013), but no records have been made for Rio Grande do Sul State. The present study reports for the first time the acanthocephalan $Q$. torquatus in two species of Astyanax from Lake Guaíba, southern Brazil.

\section{Material and Methods}

Specimens of A. eigenmanniorum $(\mathrm{n}=11)$, A. aff. fasciatus $(\mathrm{n}=44)$, $A$. henseli $(\mathrm{n}=5)$ and $A$. lacustris $(\mathrm{n}=25)$ were collected with seine nets between January 2017 and October 2017 in Pintada Island, Lake Guaíba, Porto Alegre city ( $30^{\circ} 17^{\prime} 11$ 'S and $51^{\circ} 18^{\prime} 01$ 'W), Rio Grande do Sul State, Brazil. Individual fishes were stored in separate plastic bags and kept under refrigeration until necropsy. Fishes were necropsied, and each organ was placed individually in Petri dishes. Acanthocephalans found in cysts were released and placed in distilled water for 48 hours under cold temperature. This procedure led to the evagination of the proboscis. Helminths were fixed in A.F.A. for 48 hours and then, stored in $70^{\circ} \mathrm{GL}$ ethanol (Amato \& Amato 2010). Acanthocephalans were stained with Delafield's hematoxylin, clarified and later mounted on slides using Canada balsam.
Measurements were made using an ocular micrometer in a light microscope and, are shown in micrometers $(\mu \mathrm{m})$, unless otherwise indicated, and represent the range followed between parenthesis by the mean, the standard deviation, and the sample size. Hooks and spines were measured considering the blade and root length (Brázová et al. 2014), and the base length of the hooks. Line drawings and photomicrographs were made using a Zeiss Axiostar or a Olympus BX50 microscope, scanned and prepared using CorelDraw X $4^{\circledR}$ and Adobe's Photoshop $^{\circledR}$ CS2. Ecological parameters follow Bush et al. (1997). Voucher specimens of the helminths were deposited in the 'Coleção Helmintológica do Instituto Oswaldo Cruz’ (CHIOC), Rio de Janeiro, Rio de Janeiro State, Brazil. Hosts were identified following Bertaco \& Lucena (2010) and Lucena et al. (2013). The study was approved by the Institutional Committee.

\section{Results}

Quadrigyrus Van Cleave, 1920

Quadrigyrus torquatus Van Cleave, 1920 (cystacants)

Figures 1-3

Description. Quadrigyridae, Quadrigyrinae. Based on seven specimens (five males and two females). Whitish cystacants in life, cyst free in the small intestine. Proboscis armed with 10 longitudinal rows of two hooks each, forming four transversal circles of hooks (figures 1a, $1 \mathrm{~b}, 2 \mathrm{a}$ and $3 \mathrm{a}$ ). The apical hooks present a small manubrium, slightly visible (figures 1c, 2b and 3a); all of the hooks present a well developed root. Proboscis receptacle of one muscular layer, with cerebral ganglion next to the base (figure 1b). Trunk with four transversal circles of spines in the anterior region (figures $1 \mathrm{a}, 1 \mathrm{~b}, 1 \mathrm{~d}, 2 \mathrm{a}, 2 \mathrm{c}$ and $3 \mathrm{~b}$ ). Lemnisci claviform, with large nuclei (figure 1b). Nuclei in the tegument of two types: anterior middle dorsal and medium ventral and, the others branched and lateral.

Males $(\mathrm{n}=5)$. Body $3.62 \mathrm{~mm}$ long, $0.6-0.65 \mathrm{~mm}(0.62 \pm 0.02 \mathrm{~mm})$ wide at lemnisci level and, $0.35-0.47 \mathrm{~mm}(0.43 \pm 0.05 \mathrm{~mm})$ wide at testes level. Proboscis 160 long and 150 wide. Hooks of first circle $77-87(83 \pm 4 ; \mathrm{n}=6)$ long, base $15-20(18 \pm 2 ; \mathrm{n}=6)$ long; root 50-57 $(54 \pm 2 ; n=6)$ long. Hooks of second circle $72-82(77 \pm 4 ; n=6)$ long, base $12-20(16 \pm 2 ; n=6)$ long; root $45-47(46 ; \pm 1 ; n=6)$ long. Hooks of third circle 47-55 (52 $\pm 3 ; \mathrm{n}=6)$ long, base 7-12 $(10 \pm 1 ; \mathrm{n}=6)$ long; root 20-32 (25 $\pm 4 ; \mathrm{n}=6)$ long. Hooks of fourth circle 37-45 $(41 \pm 3 ; \mathrm{n}=6)$ long, base 5-8 (7 $\pm 1 ; \mathrm{n}=6)$ long; root $12-20(16 \pm 2$; $\mathrm{n}=6$ ) long. Trunk with four transversal circles of spines, with 17 to 21 spines in each circle. Spines of the first circle 17-20 $(18 \pm 1 ; \mathrm{n}=4)$ long, root 15-17 $(16 \pm 1 ; n=4)$ long. Spines of the second circle 15-17 $(16 \pm 1 ; \mathrm{n}=5)$ long, root $12-15(13 \pm 1 ; \mathrm{n}=5)$ long. Spines of the third circle 15-17 $(16 \pm 1 ; \mathrm{n}=5)$ long, root 10-15 $(13 \pm 2 ; \mathrm{n}=5)$ long. Spines of the fourth circle $12-17(15 \pm 2 ; \mathrm{n}=5)$ long, root $12-15(14$ $\pm 1 ; \mathrm{n}=5)$ long. Proboscis receptacle 300 long, 80-150 (115 $\pm 35 ; \mathrm{n}=$ 2) long. Lemnisci 520-700 (601 $\pm 61 ; \mathrm{n}=5)$ long, 80-150 (120 \pm 27 ; $\mathrm{n}=5)$ wide. Oval testes, in tandem, 180-280 $(226 \pm 33 ; \mathrm{n}=10)$ long, 80-120 (98 $\pm 13 ; \mathrm{n}=6$ ) wide (figure $2 \mathrm{~d})$. Cement glands not visualized and, Saefftigen's pouch in development. Copulatory bursa 90-130 (108 $\pm 13 ; \mathrm{n}=5)$ long, 70-80 (78 $\pm 4 ; \mathrm{n}=5)$ wide (figure $2 \mathrm{e})$.

Females $(\mathrm{n}=2)$. Body $5.9 \mathrm{~mm}$ long, 0.62-0.75 mm $(0.69 \pm 0.06$ $\mathrm{mm} ; \mathrm{n}=2)$ wide at level of lemnisci and, 0.37-0.47 mm (0.42 \pm $0.05 \mathrm{~mm} ; \mathrm{n}=2$ ) wide at middle body. Proboscis 190 long, 180 wide. 

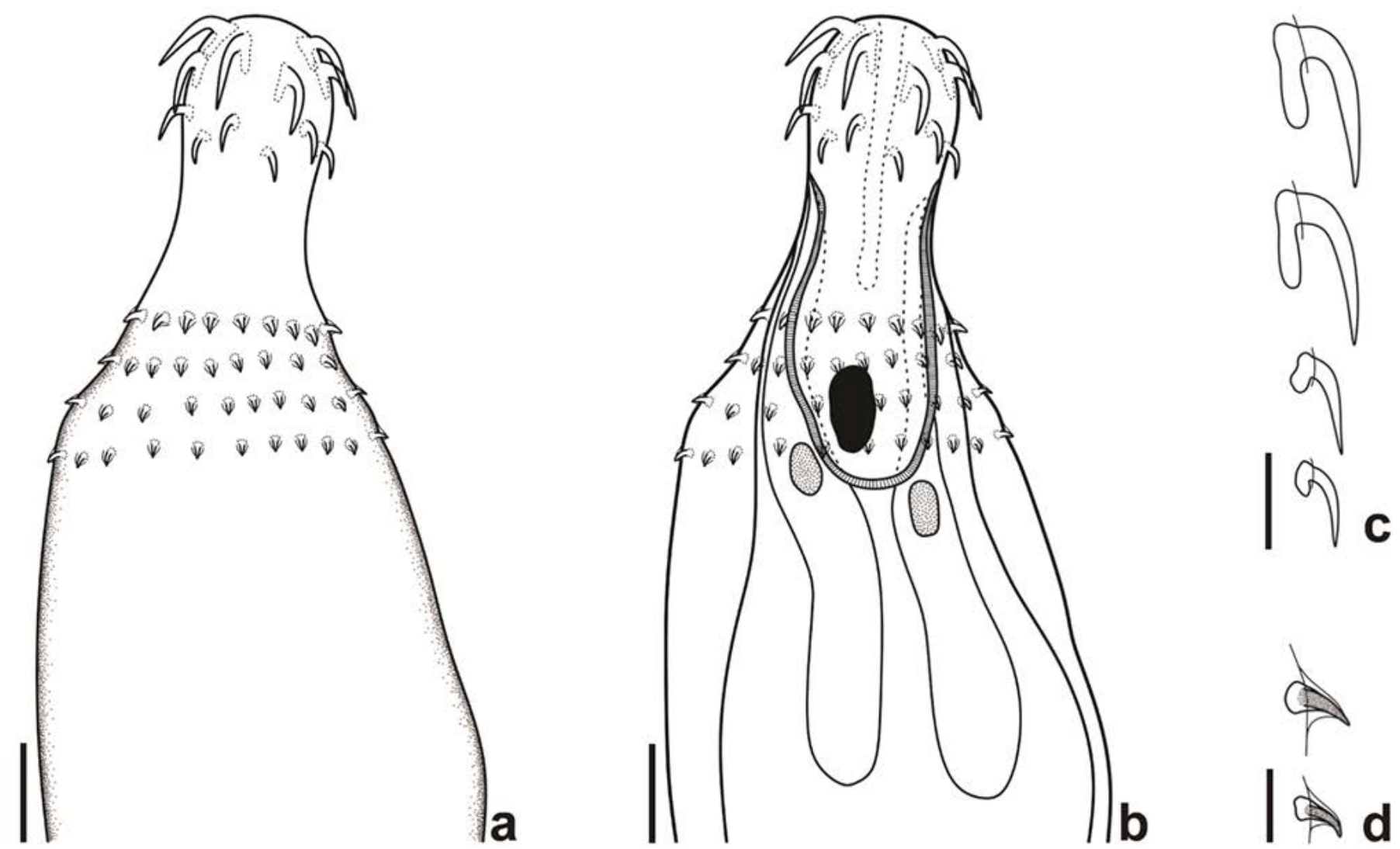

FIGURE 1. Quadrigyrus torquatus Van Cleave, 1920. a. External view of the anterior end showing the hooks in the proboscis and the spines in the trunk. Scale bar $=100 \mu \mathrm{m}$. b. Internal view of the anterior end. Scale bar $=100 \mu \mathrm{m}$. c. Hooks. Scale bar $=50 \mu \mathrm{m}$. d. Spines of the trunk. Scale bar $=20 \mu \mathrm{m}$.

Hooks of first circle 80-90 (85 $\pm 4 ; \mathrm{n}=3)$ long, base 17-20 $(18 \pm 1$; $\mathrm{n}=3)$ long; root 55-60 (57 $\pm 2 ; \mathrm{n}=3)$ long. Hooks of second circle 80-85 (82 $\pm 2 ; \mathrm{n}=4)$ long, base 17-20 (18 $\pm 1 ; \mathrm{n}=4)$ long; root $52-57(56 \pm 2 ; n=3)$ long. Hooks of third circle $55(\mathrm{n}=4)$ long, base $10(\mathrm{n}=4)$ long; root $17-25(22 \pm 3 ; \mathrm{n}=4)$ long. Hooks of fourth circle $40-47(42 \pm 3 ; n=4)$ long, base $7-10(9 \pm 1 ; n=4)$ long; root 15-17 (16 $\pm 1 ; n=4)$ long. Trunk with four transversal circles of spines, with 19 to 20 spines in each circle. Spines of the first circle 20-22 $(21 \pm 1 ; \mathrm{n}=2)$ long, root $12-15(14 \pm 1 ; \mathrm{n}=2)$ long. Spines of the second circle $17(n=2)$ long, root $15(n=2)$ long. Spines of third circle $15(\mathrm{n}=2)$ long, root 15-17 $(16 \pm 1 ; \mathrm{n}=$ 2) long. Spines of fourth circle $15(n=2)$ long, root $12-15(14 \pm 1$; $\mathrm{n}=2)$ long. Proboscis receptacle 330 long, 180-210 (195 $\pm 15 ; \mathrm{n}=$ 2) wide. Lemnisci 470-680 (575 $\pm 105 ; \mathrm{n}=2)$ long, 80-110 (95 \pm $15 ; \mathrm{n}=4)$ wide. Ovary not visualized. Uterine bell 70-80 (75 $\pm 5 ; \mathrm{n}$ =2) long, 40-50 (45 $\pm 5 ; \mathrm{n}=2)$ wide (fig 10). Uterus 230-310 (270 $\pm 40 ; \mathrm{n}=2)$ long, $30-40(35 \pm 5 ; \mathrm{n}=2)$ wide. Vagina $140-170(155$ $\pm 15 ; \mathrm{n}=2$ ) long, with two sphincters (figure $2 \mathrm{f}$ ), the anterior 50 $(\mathrm{n}=2)$ long, $57-80(69 \pm 11 ; \mathrm{n}=2)$ wide; and the posterior $20-25$
$(22 \pm 2 ; \mathrm{n}=2)$ long, $25-37(31 \pm 6 ; \mathrm{n}=2)$ wide. Genital pore $50-120$ $(85 \pm 35 ; \mathrm{n}=2)$ from posterior end.

\section{Taxonomic summary}

Hosts: Astyanax aff. fasciatus (Cuvier, 1819) and Astyanax lacustris (Lütken, 1875).

Locality: Pintada Island, Lake Guaíba, Porto Alegre city ( $30^{\circ} 17^{\prime} 11^{\prime}$ S and $\left.51^{\circ} 18^{\prime} 01^{\prime \prime W}\right)$, Rio Grande do Sul state, Brazil.

Site of infection: small intestine.

Prevalence: $6.81 \%$ (A. aff. fasciatus) and $12 \%$ (A. lacustris). Mean intensity of infections: 1 helminth/host $(A$. aff. fasciatus) and 1.66 helminths/host (A. lacustris).

Mean abundance of infections: 0.06 helminth/host $(A$. aff. fasciatus) and 0.2 helminth/host (A. lacustris).

Amplitude of intensity of infections: 1 (A. aff. fasciatus) and 1-3 (A. lacustris).

Voucher specimens of the helminths deposited: CHIOC 40060-male, CHIOC 40061- female. 
GALLAS, M. et al.
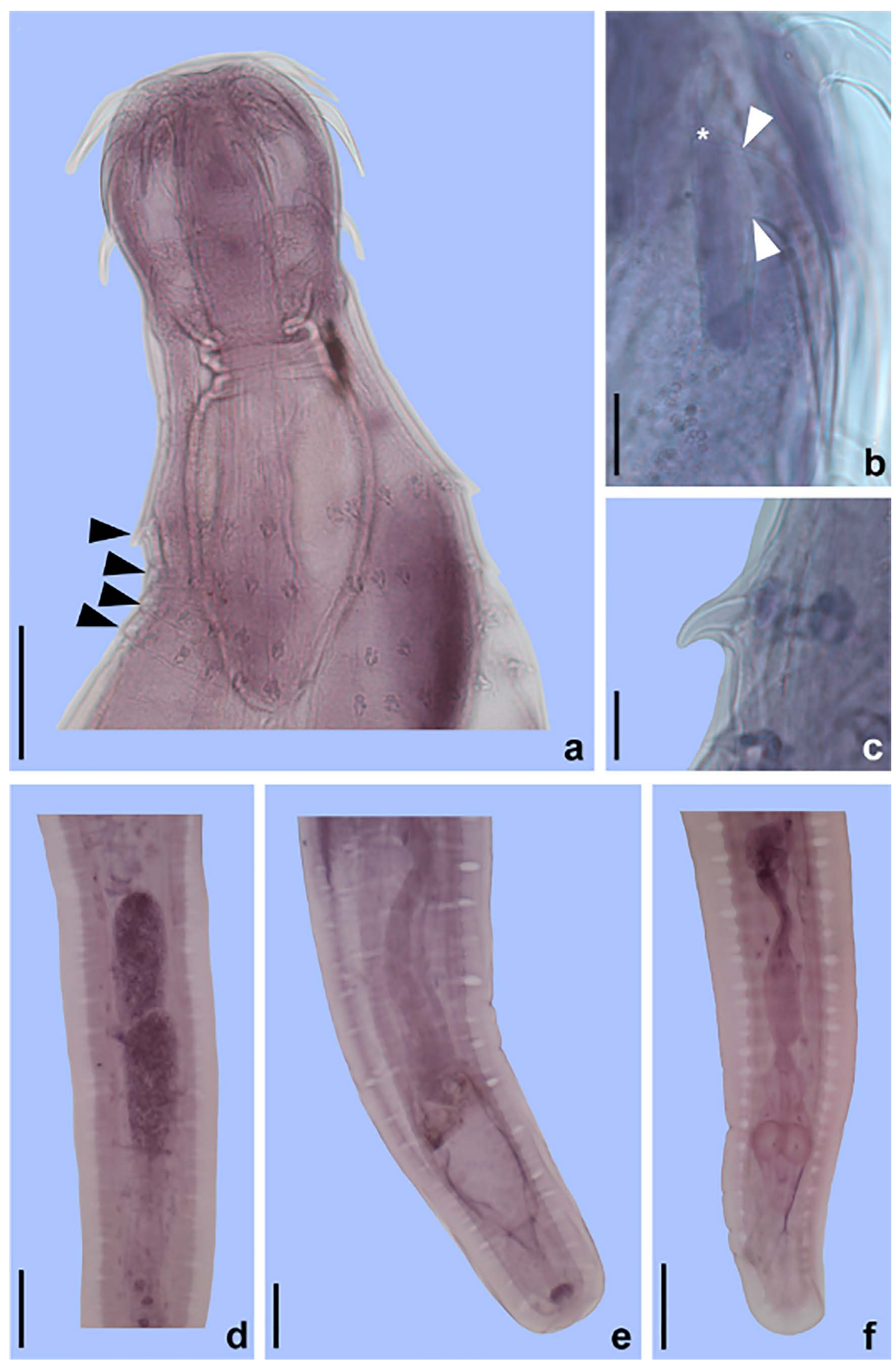

FIGURE 2. Quadrigyrus torquatus Van Cleave, 1920. a. Anterior end showing the four circles of spines (arrow heads). Scale bar $=100 \mu \mathrm{m} . \mathrm{b}$. Detail of the hook showing the limit of the blade and the small manubrium (asterisk). Scale bar $=20 \mu \mathrm{m}$. c. Detail of the spine of the trunk. Scale bar $=15 \mu \mathrm{m}$. d. Middle region of the body showing the testes. Scale bar $=150 \mu \mathrm{m}$. e. Posterior end of male. Scale bar $=150 \mu \mathrm{m}$. f. Posterior end of female. Scale bar $=100 \mu \mathrm{m}$. 

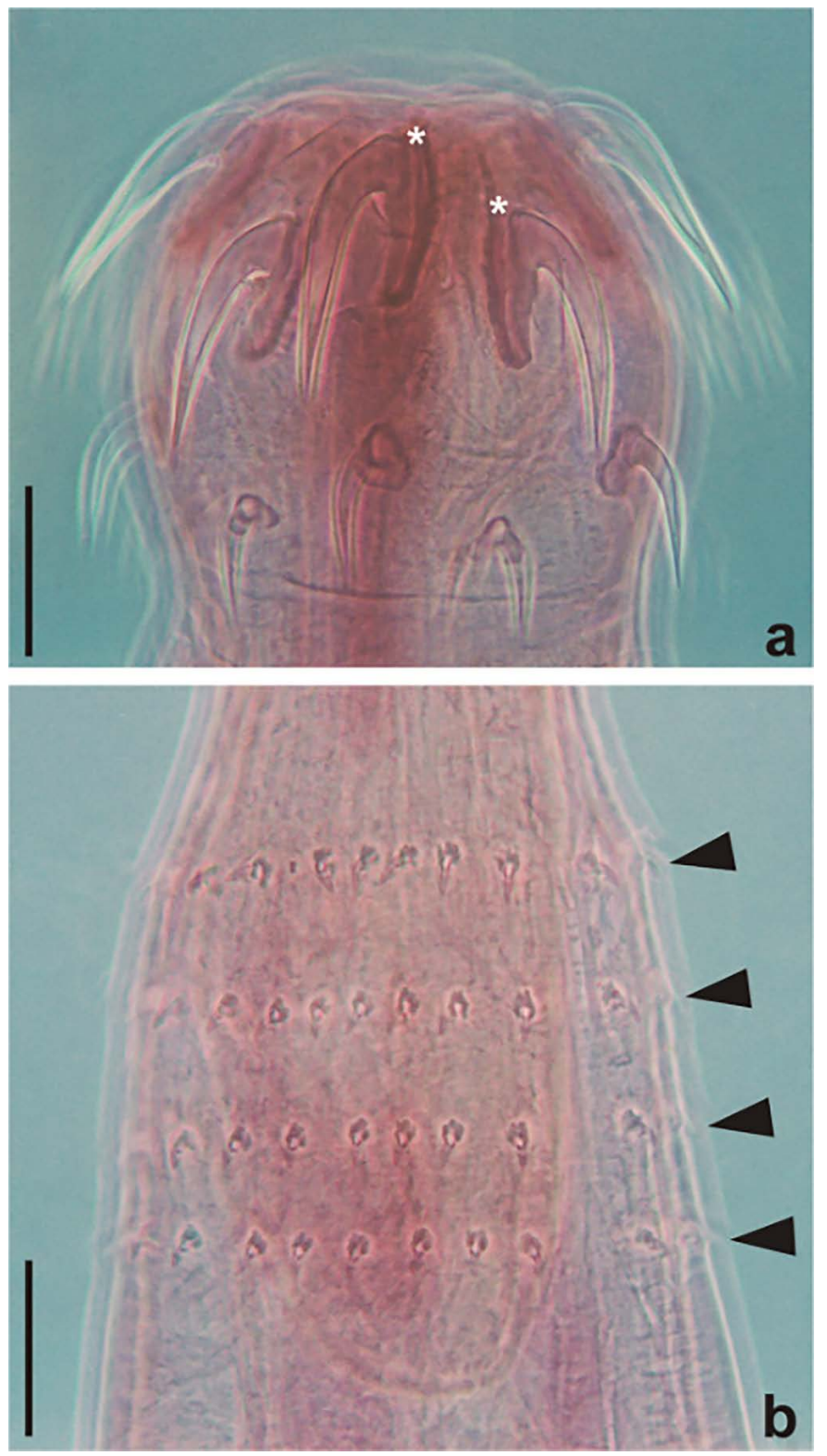

FIGURE 3. Quadrigyrus torquatus Van Cleave, 1920, observed with phase contrast. a. Anterior end showing the proboscis with a hook showing the small manubria (asterisks). Scale bar $=50 \mu \mathrm{m}$. b. Detail of the trunk showing the four circles of spines (arrow heads). Scale bar $=100 \mu \mathrm{m}$.

\section{Discussion}

The four species of Quadrigyrus reported from South America (Q. brasiliensis, Q. machadoi, Q. nickoli, and Q. torquatus) (Thatcher 2006, Santos et al. 2008, Fujimoto et al. 2013) could be differentiate by the number of rows and the quantity of spines in the trunk: $Q$. brasiliensis presents three circles with 12 spines each; $Q$. machadoi has three to six circles with spines (the number of spines by each circle is unknown); Q. nickoli presents four circles with 23 to 29 spines each (Schmidt \& Hugghins 1973, Fabio 1983, Thatcher 1991). However, the descriptions of the quantity of spines in the trunk of $Q$. torquatus vary in the literature. For example, Van Cleave (1920) reported specimens with four circles of spines (the number of spines was not informed in the text, but from the drawings, about 10 spines could be observed in one view); Schmidt \& Hugghins (1973) found specimens with three to four circles of 10 to 18 spines each, an description also found in Thatcher $(1991,2006)$, which possibly compiled data from Schmidt \& Hugghins (1973).

The specimens found in the present study presented four circles of spines; however the quantity of spines by circle was higher (17-21) than the amount (10-18) reported by Schmidt \& Hugghins (1973). According to Van Cleave (1920), the quantification of spines in mature specimens of $Q$. torquatus is more difficult than in the young specimens, and this could be the reason for the low number of spines observed by Schmidt \& Hugghins (1973). Although the number of spines in the trunk of $Q$. nickoli (23-29) is similar to the maximum number of the spines (21) in the specimens found in the present study, the size of the hooks and the amount of spines led the morphological identification of the cystacants as $Q$. torquatus.

The prevalence of $Q$. torquatus seems to be lower in the paratenic hosts $A$. aff. fasciatus $(6.81 \% ; \mathrm{n}=44)$ and A. lacustris $(12 \% ; \mathrm{n}=$ 25) found in the present study, and Leporinus lacustris Campos, $1945(1.33 \% ; \mathrm{n}=150)$ (Guidelli et al. 2006), in relation to the definitive hosts Acestrorhynchus lacustris (Lütken, 1875) (37.2\%; n =51) (Carvalho et al. 2003). The difference in the prevalence could be related to several factors, such as host life habits and feeding (freshwater fish hosts with an omnivorous or piscivorous diet are frequently parasitized by acanthocephalans), and characteristics related to the parasite life cycle (presence of the intermediate hosts in the environments, and the fact that the larvae must be ingested by a suitable host) (Nickol 1985, Kennedy 2006). The number of hosts examined in each study could also influence the prevalence, since this parameter is obtained considering the number of hosts parasitized and non-parasitized (Bush et al. 1997). More studies are necessary to confirm the hypothesis of the high-low prevalence of $Q$. torquatus in different types of hosts.

In the life cycle of the species of Quadrigyrus, carnivore fish are considered to be the definitive hosts, and two species of Astyanax (A. bimaculatus and Astyanax altiparanae Garutti \& Britski, 2000) have been reported as paratenic hosts (Van Cleave 1920, Carvalho et al. 2003, Rosim et al. 2005, Lizama et al. 2008, Fujimoto et al. 2013). The presence of $Q$. torquatus in $A$. aff. fasciatus and $A$. lacustris in this study reflects the position of these fish in the food web: the characids are paratenic hosts harboring the cystacants of Q. torquatus which will reach the adult stage after being eat by a carnivore fish (definitive host).

The richness of the species of acanthocephalans parasitizing Astyanax spp. in South America is extremely low, with reports in A. bimaculatus (Van Cleave 1920, Fujimoto et al. 2013) and A. altiparanae (Lizama et al. 2008). The following species were reported as definitive or paratenic hosts of $Q$. torquatus in Brazil: $A$. bimaculatus, Ac. lacustris, H. malabaricus, L. lacustris e Moenkhausia sanctaefilomenae (Steindachner, 1907) (Machado Filho 1941, Carvalho et al. 2003, Guidelli et al. 2006, Santos et al. 2008, Fujimoto et al. 2013). This is the first report of $Q$. torquatus cystacants in $A$. aff. fasciatus and A. lacustris from Lake Guaíba, extending the distribution to the southernmost state of Brazil. The present study contributes to the knowledge of the helminth fauna of species of Astyanax in freshwater ecosystems, the most rich and threatened environments on Earth (Geist 2011). 


\section{Acknowledgements}

The authors are grateful to Bucal Pathology Laboratory (Faculty of Odontology), PUCRS for permission to use the microscope to take the photomicrographs; MG thanks the Brazilian National Research Council (CNPq) for financial support (process number 140639/2016-0).

\section{Author Contributions}

Moisés Gallas: Substantial contribution in the concept and design of the study; Contribution to data collection; Contribution to data analysis and interpretation; Contribution to manuscript preparation; Contribution to critical revision, adding intelectual content.

Laura R. P. Utz: Contribution to manuscript preparation; Contribution to critical revision, adding intelectual content.

\section{Conflicts of interest}

The authors declare that they have no conflict of interest related to the publication of this manuscript.

\section{Ethics}

The study is approved by the Institutional Committee.

\section{References}

AMATO, J.F.R. \& AMATO, S.B. 2010. Técnicas gerais para coleta e preparação de helmintos endoparasitos de aves. In Ornitologia e Conservação: Ciência Aplicada, Técnicas de Pesquisa e Levantamento (S. VON MATTER et al., Orgs.). Technical Books, Rio de Janeiro, p. 369-393.

AMIN, O.M. 2013. Classification of the Acanthocephala. Folia parasitol. 60(4): 273-305.

BERTACO, V.A. \& LUCENA, C.A.S. 2010. Redescription of Astyanax obscurus (Hensel, 1870) and A. laticeps (Cope, 1894) (Teleostei: Characidae): two valid freshwater species originally described from rivers of Southern Brazil. Neotrop. ichthyol. 8(1): 7-20.

BRÁZOVÁ T., PODDUBNAYA L.G., MISS, N.M. \& HANZELOVÁ, V. 2014. Ultrastructure and chemical composition of the proboscis hooks of Acanthocephalus lucii (Müller, 1776) (Acanthocephala: Palaeacanthocephala) using X-ray elemental analysis. Folia parasitol. 61(6): 549-557.

BUSH, A.O., LAFFERTY, K.D., LOTZ, J.M. \& SHOSTAK, A.W. 1997. Parasitology meets ecology on its own terms: Margolis et al. revisited. J. Parasitol. 83(4): 575-583.

CARVALHO, S., GUIDELLI, G.M., TAKEMOTO, R.M. \& PAVANELLI, G.C. 2003. Ecological aspects of endoparasite fauna of Acestrorhynchus lacustris (Lütken, 1875) (Characiformes, Acestrorhynchidae) on the Upper Paraná River floodplain, Brazil. Acta Sci. Biol. Sci. 25(2): 479-483.

FABIO, S.P. 1983. Sobre alguns Acanthocephala parasitos de Hoplias malabaricus. Arq. Univ. Fed. Rural Rio J. 6(2): 173-180.

FORTES, E. \& HOFFMANN, R. P. 1999. Trematódeos gastrintestinais de Astyanax fasciatus (Cuvier, 1819), lambaris do Lago Guaíba, Porto Alegre, Rio Grande do Sul, Brasil. Hora Vet. 18(108): 55-56.

FUJIMOTO, R.Y., BARROS, Z.M.N., MARINHO-FILHO, A.N., DINIZ, D.G. \& EIRAS, J.C. 2013. Parasites of four ornamental fish from the Chumucuí River (Bragança, Pará, Brazil). Rev. Bras. Parasitol. Vet. 22(1): 34-38.
GALlAS, M., CALEGARO-MARQUES, C. \& AMATO, S.B. 2014. A new species of Cacatuocotyle (Monogenea, Dactylogyridae) parasitizing two species of Astyanax (Ostariophysi, Characidae) in southern Brazil. Acta parasitol. 59(4): 638-642.

Gallas, M., CAlegaro-Marques, C. \& AMATO, S.B. 2015. Supplemental observations on the morphology of Procamallanus (Spirocamallanus) hilarii (Nematoda: Camallanidae) parasitizing two species of Astyanax (Characiformes: Characidae) and ecological analyses. Rev. Mex. Biodivers. 86(3): 590-596.

GALlAS, M., CALEGARO-MARQUES, C. \& AMATO, S.B. 2016. A new species of Characithecium (Monogenea: Dactylogyridae) from external surface and gills of two species of Astyanax (Ostariophysi: Characidae) in southern Brazil. Rev. Mex. Biodivers. 87(3): 903-907.

GEIST, J. 2011. Integrative freshwater ecology and biodiversity conservation. Ecol. Indic. 11(6): 1507-1516.

GUIDELLI, G., TAVECHIO, W.L.G., TAKEMOTO, R.M. \& PAVANELLI, G.C. 2006. Fauna parasitária de Leporinus lacustris e Leporinus friderici (Characiformes, Anostomidae) da planície de inundação do alto rio Paraná, Brasil. Acta Sci. Biol. Sci. 28(3): 281-290.

KENNEDY, C.R. 2006. Ecology of the Acanthocephala. Cambridge University Press, Cambridge.

LIZAMA, M.A.P., TAKEMOTO, R.M. \& PAVANELLI, G.C. 2008. Ecological aspects of metazoan parasites of Astyanax altiparanae Garutti \& Britski, 2000 (Characidae) of the upper Paraná River floodplain, Brazil. Bol. Inst. Pesca 34(4): 527-533.

LUCENA, C.A.S., CASTRO, J.B. \& BERTACO, V.A. 2013. Three new species of Astyanax from drainagens of southern Brazil (Characiformes: Characidae). Neotrop. ichthyol. 11(3): 537-552.

LUCENA, C.A.S., ZALUSKI, A.B. \& LUCENA, Z.M.S. 2017. Astyanax taurorum a new species from dos Touros River, Pelotas River drainage, an upland southern Brazilian river (Characiformes: Characidae). Zoologia 34: e20174.

MACHADO FILHO, D.A. 1941. Sobre alguns acantocéfalos provenientes do estado de Mato Grosso. Rev. Bras. Biol. 1(1): 57-61.

NICKOL, B.B. 1985. Epizootiology. In Biology of the Acanthocephala (D.W. CROMPTON \& B.B. NICKOL, Eds). Cambridge University Press, Cambridge, p. 307-346.

ROSIM, D.F., CECCARELLI, P.S. \& SILVA-SOUZA, A.T. 2005. Parasitismo de Hoplias malabaricus (Bloch, 1794) (Characiformes, Erythrinidae) por Quadrigyrus machadoi Fabio, 1983 (Eoacanthocephala, Quadrigyridae) de uma lagoa em Aguaí, Estado de São Paulo, Brasil. Rev. Bras. Parasitol. Vet. 14(4): 147-153.

SANTOS, C.P., GIBSON, D.I., TAVARES, L.E.R. \& LUQUE, J.L. 2008. Checklist of Acanthocephala associated with the fishes of Brazil. Zootaxa 1938: 1-22.

SCHMIDT, G.D. \& HUGGHINS, E.J. 1973. Acanthocephala of South American Fishes. Part I, Eoacanthocephala. J. Parasitol. 59(5): 829-835.

THATCHER, V.E. 1991. Amazon fish parasites. Amazoniana 11(3/4): 263-572.

THATCHER, V.E. 2006. Amazon Fish Parasites. Volume I. Pensoft Publishers, Sofia.

VAN CLEAVE, H.J. 1920. Two new genera and species of acanthocephalous worms from Venezuelan fishes. Proc. U. S. Natl. Mus. 58(2346): 455-466.

Received: $16 / 11 / 2018$

Revised: 26/02/2019

Accepted: 15/04/2019

Published online: 23/05/2019 